\title{
Study on Problems and Countermeasures of University Students Running Mechanism
}

\author{
Jie Bian \\ College of Music ,Jiangxi University of Technology
}

Keywords: University students work; Running mechanism; Existing problems; Countermeasures.

\begin{abstract}
For students work, establishing a scientific and reasonable management system, straightening out various relationships and forming good working mechanism can guarantee to ensure effective and safe student work to better serve education and talent cultivation. This paper starts from the connotation of student work mechanism and explain the condition in Hong Kong, Canada, United States and United Kingdom. What's more, it elaborates the running condition of domestic and foreign universities as well as the existing problems, puts forward the idea of human-orientation to strengthen the student team construction as well as working system construction, innovate the working system, develop the working efficiency, management ability of students and guarantee the student work system running.
\end{abstract}

\section{Introduction}

Domestically, domestic student work can be traced back to the early days of establishing the party when some military schools and training institutions set up some training mechanisms. To be strict, it starts from the period of establishing the country. The student work in China generally experienced three phases: growth period (1949-1966), desperate period (1966-1976), and development and perfection period (1977-now). After 1990s, the student work management model gradually becomes mature. In 2004, the issuing of Central Committee of CPC and State Council Deciding to Strengthen and Improve the Ideological and Political Education provided policy basis and cleared the development direction for student word, which strengthened the confidence of relevant workers and pushed the student work into a gold development period.

At present, the scholar circle has carried out a dazzling array of researches on the student team work construction and education management with great performance. However, researches on the running system of student work are few. In China journals full text database, there are only 14 articles about the running system of student work. For example, Zhu Lingyun Research on the Student Work Running System in New Situation (Beijing City College journal, 2008/05); Huang Yongle Considerations on Establishing Sound Student Work Running System (Heilongjiang higher education research, 2004/11); Cai Libin Research and Practice of the Student Work Runing System in Colleges and Universities (Serial, 2004/09); Wang Yaohui Research on the Student Work System Under Credit System (Journal of China three gorges University (Humanities and social sciences), 2002/04).)

Other documents related to the running system are limited to education, management, teaching, funding, and campus management without general mastering of student work. 
Even though, there are few researches there are penetrating views. Based on above document analysis, the research results mainly show in the following aspects:

Firstly, the student work running system is divided into school and institution level, including seven major elements, namely education mechanism, management mechanism, protection mechanism, assessment mechanism, incentive mechanism safeguard mechanisms, and consultative mechanisms etc which contains three relations such as the relation among relevant institutions, the coordinated relation and relation between business process and responsibilities. It elaborates reasonable and efficient methods to construct the student work running system so as to achieve mutual complementary effect and serve the full and comprehensive development of students. Secondly, it holds the idea that student work in colleges and universities has a tendency of ruling by men, so we have to establish a sound mechanism. In addition, we have to establish a sound evaluation system, improve the student quality assessment system, realize the healthy development, establish a competition incentive mechanism to stimulate the ability of all students and establish an assessment system for the whole institution. Thirdly, college and university students should work around teaching so as to promote all-round development and shape good quality. Moreover, we have to establish a sound mechanism in terms of education, management and service, trying unremitting efforts to cultivate high quality and innovative talents to effectively push the innovation and development of moral education as well as the revolution and development of higher education; fourthly, we should combine relevant background. For example, we can put forward our understandings of the student work running system construction based on analysis on the challenges of students as well as their role and function under credit system.

Based on the document analysis, we have the following problems: firstly, we haven't found the generality and particularity of student work running system; secondly, there is discussion on a certain aspect of the running system but researches on the horizontal and vertical relationships are rare; thirdly, there are fewer researches on the guarantee of the mechanism; fourthly, we have not conclude the running system which will affect students as well as the solutions.

\section{The connotation of student work running system in colleges and universities}

Student work: In different historical periods, the content of student work is different. But with the student work in colleges and universities becoming more and more complicated, the traditional moral education cannot be equal to the student work.

Scholars have different views about the definition of student work. Some scholars believe that the students ' work refers to the work of students ' ideological and political education, that is, moral education while some stick to the idea that ideological and political education as well as intellectual, physical and aesthetic education can be regarded as organic parts of school education to form unique moral education. What's more, some scholars believe that traditionally student work refers to the ideological and political education as well as daily management.

Work related to students in foreign universities is often referred to as student affair, which typically refers to organizational service, including comprehensive quality education, student activities, residential services, psychological problems of students. Student affair management is the general name for work and is basically correspond to student work in colleges and universities in China.

Student work in colleges and universities has its unique connation. If it is combed from the fundamental task perspective, it contains three aspects: 
Judging from a macro perspective, the fundamental task of higher education is to cultivate talents. And the talents refer to the undergraduate and college students who receive education in general colleges and universities.

Judging from a median perspective, student work is to carry out political guidance, ideological education, behavior and affair management which include reward, loan, subsidy and reducing tuition fee etc. Actually, it aims to elaborate the function of student work department.

Judging from a micro perspective, it refers to the student work of departments in universities and colleges which are the practitioners to implement the educational policy as well as the ones to implement the guidance ideas, aiming to foster innovative talents.

We believe that, in theory, generalized work refers to the summation of direct and indirect work which can help to promote the health growth of students. In narrow sense, student work refers to the school affairs which are parallel to teaching and scientific research. In practice, student work in colleges and universities is an important and indispensable content to realize the target, which is defined as the summation of the activities school managers carry out to meet the requirements in terms of cultivating emotion, improving knowledge and developing exercise ability.

1.2 Running mechanism: Ushinski, a famous Russian educator once said that schools have three elements: administrative management, education and research. In order to implement teaching and scientific research, we have to depend on the administrative management.

Mechanism is a noun, mainly refers to organizational systems of state organs, enterprises, institutions and organizations which can also be regarded as the text and pattern. Running mechanism is a verb phrase, aims to make the work smoothly. Student work is a difficult and complex engineering system which tries to scientifically and reasonably establish work management system and rationalize various relationships to form sound work running system in order to ensure orderly, effective work to guarantee the teaching and talents cultivation.

\section{Overview of the student work running system at home and abroad}

Student work running system in Hong Kong: Colleges and universities in Hong Kong set student affairs offices to be responsible for the affairs except lessons which directly report to the vice president in charge. These offices manage student groups, which are the most authoritative institutions. Inside these offices, there are many branches divided based on different affairs with weak administrative functions yet clear division of labor so as to respectively deal with affairs smoothly.

Student work running system in Canada: the system clearly elaborates duties and responsibilities which is effective and can fully play the role of student assistant and volunteers. In General, a vice president or a senior is responsible for various department of this system and the logistics service should be taken by students in order to let students know the purpose for serving students. There are rare office managers and some offices only have one to be responsible for the contact with student union and the organization of freshmen orientation as well as graduation guidance. The freshmen orientation is similar to the opening ceremony and entrance education.

Student work running system in America: Like colleges and universities in China, America also pays attention to the university student work with sound rules and regulations as well as professional student work institutions. Besides, these institutions are equipped with students to implement ideological and political education. 
Student affairs as well as management activities in American colleges and universities are carried out by the school. In terms of student work organization structure, the student affair management institution setting and authority allocation are only decided by the most authoritative department of school without relevant organization and labor demands. Based on the labor division, various offices directly carry out work. The concrete running procedure is: student individual-various offices-assistant of vice president-vice president-president.

Student work running system in England: In terms of student work running system, there is not vice president to be responsible for student work in United Kingdom universities and colleges and the director of student service department is responsible for student affairs and acts the role as the secretary of University Council. Student service department is an important department, which directly faces students. Personal tutor system is a system which has always been supported by England and there is not a professional institution to be responsible for student affairs. Once a student is enrolled, the college shall assign one tutor to every student.

\section{The student work running systems in Chinese colleges and universities}

Good institution setting is the guarantee to carry out smooth student work, which is the proof of dynamic existence. Relevant organizational institutions directly affect the quality and effect of student work. Therefore, as dynamic carriers, the running system plays a vital role in student work.

Student work in colleges and universities should face the full development and talent cultivation target so as to shape all-round development students. In addition, a sound running system in terms of education, management and service should be established to foster high-quality and innovative talents to finally push the development of moral innovation and development as well as the reform and development of higher education.

The student work running system in Chinese colleges and universities. We think that there are vertical and horizontal running systems in student work. The vertical running system refers to the relation between superiors and subordinates and the work is carried out step by step. The horizontal running system refers to coordinated work among different layers.

The function of main institutions and elements in student work. Party committee plays a central role

Experiences tell us that the Party committee as the central role takes the politic as well as leadership responsibilities. Throughout the whole running system, it plays a central role. In student work, the school should fully take advantage of its function to implement work.

The functional department and party committee of colleges and department should implement work

Dormitory management service department

Student dormitory is one of the important places of learning and living, which plays a very important role in students' healthy development. To play the education role of dormitory is an indispensable sector in educating people. We have to change the concept to play its function of educating and serving people to strengthen the effectiveness based on effective management and solutions.

The consecutive operation function of office, Communist Youth League Committee and tutors

Office, Communist Youth League Committee and tutors are direct executors and undertakers of student work so they have to correctly convey the work and manage well the labor division.

Student groups such as student union and Graduate Student union should play a linking role 
Student union and graduate student union are mass organizations and important forces to strengthen and improve the ideological and political education for university students, which are also organizers for university students to realize self-development. In addition, these two unions should accept the guidance of the party to carry out effective ideological and political education under the guidance of China Communist Youth League so as to make it betters serve as a bridge linking society and schools.

Class, Youth League branch and association should play a role to unite, organize and educate students

Class is the basic form of University students and important carrier to help them realize self-education, self-management and self-service. In real work, we have to emphasize the class construction and fully play the function of class cadres to enrich the interest of class.

\section{Existing problems in the student work running system}

The education philosophy remains to be improved. Affected by traditional culture, college and universities are beckoned as the objectives of education and management and they tend to live a smooth life. Besides, their work is regulated without democracy. The management idea of students lags behind and we cannot take students as equal party. Nowadays, higher education has changed from elite education to public education with expanded education scale and sky rocketing students. The government no longer monopolizes employment and implements two-way selection as well as self-employment policy. It is admitted that paying fees to go to school is a kind of consumption and the cultivation process is to keep the promise. To some extent, the relationship between students and schools has changed from rights and obligations into consumption and service and schools will provide full and high quality services as their duties.

The student work team remains to be strengthened. Stable and professional student work team can guarantee the healthy and sustainable development of colleges and universities. At present, the quality of managers who are engaged in the student affair is poor which mainly shows in low academic level. Generally speaking, the level of education is related to the innovation ability. What's more, the information quality is not high and they have poor ability in applying modern technology. Moreover, students do not have innovative consciousness as well as ability which mainly show in the condition that relevant managers in terms of student work lack ability to master the frontier knowledge and information technology.

\section{The administrative management is relatively bureaucratic}

Colleges and universities in China are run under condition of planned economy and the basic task of the school is to cultivate talents. To some extent, colleges and universities are affiliated unit of government and the administrative order of the state plays a decisive role in making running philosophy and system. Under the condition of planned economy, schools make the plans and students have no choice. Even though with the deepening reform of higher education reform the credit system is gradually implemented and colleges as well universities take human-orientation as the running philosophy to gradually protect the legal rights of students and improve the school condition. Besides, students begin to have choices yet the main management approaches are regulation, monitoring and punishment so it takes time to embrace service and development into student work.

Individual combat is common. The cross function seriously affects the professional level of student affair. Non-student work units exist in colleges and universities and some exist in part time 
department. In general, the director of student work is only related to student union and Youth League Committee and departments interrelated to students, restaurants, hospitals, and sports department are excluded. For example, when relevant student work department implement the function of ideological and political education, they have to contact with dean's Office, logistics, security, finance etc and their work efficiency and service level shall be affected because of different leaders and coordination level. As a result, it is difficult to solve student affairs and some departments believe that students should not solve the problems and they only trust the student work running system.

The autonomy of students is poor. Take the student union in colleges and universities as an example. Even though, the student union is playing a more and more significant role, they are not totally independent, which depends on the competent authorities of school. Besides, the main cradles are not selected by students. The student union which is not independent from economy to organizational form makes it difficult to carry out complete self-management.

\section{The student work running system policy}

Firmly establish the people-oriented student work philosophy

Create a good education atmosphere (Leaders should pay attention to; teachers should positively participate in; other functional departments should actively corporate with a strong will; deep explore social resources)

Strongly strengthen student team construction (Strictly control entrance condition; take concrete measures, trying to develop the quality of students; perfect the management system; stick to the professional trend)

Innovate the student work mechanism and system to construct effective work student running system

Perfect the student work running system (The meaning to innovate the student work running system; suggestions to set up a student work running system)

Adopt new technique means to develop work efficiency (Set up regular meeting system; old management system; evaluation incentive system; the democratic supervision system)

Explore new model to cultivate students' management ability

Strengthen the guarantee system construction (environmental protection; theoretical support; condition security)

\section{Conclusions}

This paper studies on the student work running system in colleges and universities at home and abroad and introduces the condition in Hong Kong, Canada, America and England. Besides, it highlights the student work running system at mainland China so as to find out existing problems and put forward relevant countermeasures.

\section{References}

[1]Liu Jingmin. Comparison and analysis of student work and affairs in colleges and universities in China and America. World Education Information, 5th edition of 2007 
[2]Ma Yuan. Research on the Generalization and Policy of University Student Work. Social Science Edition, 3rd Edition Section 9, June 2005.

[3] Liu Zhikan. Explore on the Practice Approach of Student Work in Colleges and Universities. China Electric Power Education. March 2009

[4]Ma Donghui, Wen Fuxiang. Comparison on the Student Affair Management in Hongkong and Student Work in Mainland China. Modern Education Science. 7th edition of 2002

[5] Gao Yangwen. Research on the Comparison of Student Work in Hong Kong and Mainland China. Journal of National Academy of Education Administration, 2004.6

[6] Yu Haihong. Research on the Comparison of Student Work in China and Canada. Ideological and Political Education Research, 1st edition of 2004.

[7]Gao Yanwen.

[8] Wang Wenke. Work organization structure comparison and enlightenment in Chinese and American Colleges and Universities. China Youth Study, 10th edition 2005

[9].Dai Qiuju, Kang Yinping. Student work comparison and enlightenment in Chinese and American Colleges and Universities. Huxiang Forum, 3rd edition of 2007

[10]Li Yongshan. Student work comparison and enlightenment in Chinese and English Colleges and Universities. China Youth Study, 8th of 2008 